\title{
Bioactivities and Analysis of Peptides of Sumbawa Horse Milk Generated by Bacillus thuringiensis Protease
}

\author{
Kusumaningtyas $\mathrm{E}^{1}$, Widiastuti $\mathrm{R}^{1}$, Kusumaningrum $\mathrm{HD}^{2}$, Suhartono $\mathrm{MT}^{2}$ \\ ${ }^{1}$ Indonesian Research Center for Veterinary Science, Jl. RE Martadinata, Bogor 16114, Indonesia \\ ${ }^{2}$ Department of Food Science and Technology, Faculty of Agricultural Technology, Bogor Agricultural University \\ Jl. Dramaga PO Box 220, Bogor 16002, Indonesia \\ E-mail: enikusuma@yahoo.com
}

(received 15-08-2016; revised 11-11-2016; accepted 23-11-2016)

\begin{abstract}
ABSTRAK
Kusumaningtyas E, Widiastuti R, Kusumaningrum HD, Suhartono MT. 2016. Bioaktifitas dan analisis peptida dari susu kuda Sumbawa yang dihasilkan oleh protease Bacillus thuringiensis. JITV 21(4): 244-254. DOI: http://dx.doi.org/10.14334/jitv.v21i4.1627

Susu kuda Sumbawa dipercaya dapat menyembuhkan berbagai penyakit seperti asma, hipertensi, diabetes dan gastrointestinal, tetapi potensi peptida bioaktifnya belum dieksplorasi. Tujuan dari penelitian ini adalah untuk mengevaluasi bioaktivitas peptida hidrolisat protein susu kuda Sumbawa dan menganalisis sifat fisiko kimia peptida terpilih. Protein susu dihidrolisis dengan protease Bacillus thuringiensis, peptida yang diperoleh difraksinasi bertingkat kemudian dianalisis aktivitas antibakteri dan antioksidan. Fraksi peptida <3 kDa kemudian disekuensing menggunakan LCMS-MS dan dianalisis sifat fisiko-kimianya. Hasil penelitian menunjukkan bahwa fraksi peptida $<3 \mathrm{kDa}$ dari hidrolisis 30 menit paling aktif sebagai antibakteri dan lebih aktif terhadap bakteri Gram negatif. Untuk antioksidan, aktivitas antioksidan fraksi tersebut per $\mu \mathrm{g}$ protein $/ \mathrm{mL}$ adalah $83 \%$ terhadap radikal ABTS dan 31\% terhadap radikal DPPH. Nilai tersebut setara dengan vitamin C $12.5 \mathrm{mg} / \mathrm{mL}$ untuk ABTS dan 14.5 $\mathrm{mg} / \mathrm{mL}$ untuk DPPH. Peptida HPYFYAPELLYYANK dengan prediksi berat molekul 1887.92 Da dengan titik isoelektrik 7.47 mempunyai indek terapi prediksi yang tinggi (64.75). Hasil tersebut menunjukkan bahwa peptida dari susu kuda Sumbawa yang dihidrolisis menggunakan protease Bacillus thuringiensis aktif sebagai antibakteri dan antioksidan. Peptida HPYFYAPELLYYANK dari fraksi $<3 \mathrm{kDa}$ berpotensi sebagai antibakteri.
\end{abstract}

Kata Kunci: Bacillus thuringiensis, Peptida Bioaktif, Susu Kuda

\begin{abstract}
Kusumaningtyas E, Widiastuti R, Kusumaningrum HD, Suhartono MT. 2016. Bioactivities and analysis of peptides of Sumbawa horse milk generated by Bacillus thuringiensis protease. JITV 21(4): 244-254. DOI: http://dx.doi.org/10.14334/jitv.v21i4.1627

Sumbawa horse milk is claimed to cure some diseases such as asthma, hypertension, diabetes and gastrointestinal disorder but its potential bioactive peptide has not been explored. The aims of this study are to evaluate bioactivities of peptides from Sumbawa horse milk protein hydrolysate and to analyzethe physio-chemical properties of selected peptides. The milk protein was hydrolyzed by Bacillus thuringiensis protease, the peptide produced were sequential fractionated and then analyzed for antibacterial and antioxidant activities. The peptide fraction $<3 \mathrm{kDa}$ was then sequenced using LCMS-MS and the physiochemical properties of the peptides were analyzed. Result showed that peptides fraction $<3 \mathrm{kDa}$ from the 30 min hydrolysis was the most active as antibacterial and more active to Gram negative bacteria. For antioxidant, scavenging activity of the fraction per $\mu \mathrm{g}$ protein $/ \mathrm{mL}$ were $83 \%$ to ABTS and $31 \%$ to DPPH radicals. The values were similar with vitamin C $12.5 \mu \mathrm{g} / \mathrm{mL}$ for ABTS and $14.5 \mu \mathrm{g} / \mathrm{mL}$ for DPPH. Peptide HPYFYAPELLYYANK with molecular weight prediction $1887.92 \mathrm{Da}$ and isoelectric point 7.47 has high therapeutic index prediction (64.75). The result showed that peptides from Sumbawa horse milk hydrolyzed by Bacillus thuringiensis protease was active as antibacterial and antioxidant. Peptide HPYFYAPELLYYANK from fraction $<3$ $\mathrm{kDa}$ was potential as antibacterial.
\end{abstract}

Key Words: Bacillus thuringiensis, Bioactive Peptide, Horse Milk

\section{INTRODUCTION}

Horse milk is minor importance in milk production in comparison to cow and goat milk. Resemblance with human milk in many respect make horse milk have been traditionally important and claimed to have special therapeutic properties. Overall, horse milk is considered to be highly digestible, rich in essential nutrient and possesses an optimum whey: casein protein ratio, making it suitable in pediatric dietetic (Potocnik et al. 2011). Nutritional and therapeutic properties are also beneficial for elderly diet. Around 30 million people consume horse milk regularly throughout the world. In Turks, Bashkirs, Kazaks, Mongol, Yakuts and Uzbeks they make lactic-alcoholic beverage called Koumiss (Potocnik et al. 2011). Domnez et al. (2014) reported 
that triglyceride and cholesterol were decreased but high density lipoprotein (HDL) was increased significantly after consumption of Koumiss for 15 days. Administration of koumiss to cancer patients was able to decrease adverse effect of chemotherapy (UniackeLowe et al. 2010)

In Indonesia, Sumbawa horse milk is claimed to cure some diseases such as asthma, hypertension, diabetes and gastrointestinal disorder. Sumbawa is one of the eastern island of Indonesia. Horse is widely grazing in the forest throughout the year. Fractionation of Sumbawa horse milk with different polarity showed that whey protein fraction, soluble in acetone exhibited significant inhibition on the growth of $S$. agalactiae and S. pyogenes (Detha et al. 2013). Sumbawa horse milk not only contains beneficial protein and good microorganism but may also contain bioactive peptides yielding by enzymatic hydrolysis of bacterial protease.

Bacillus thuringiensis is an endospore-forming bacteria which is commonly found in soil, water, plants, stored cereal, dead insect, animal feces (Argolo-Filho \& Loguercio 2014), milk before or after pasteurization (Zhou et al. 2008), fresh fruit and vegetable (Frederiksen et al. 2006). Some researchers found $B$. thuringiensis as part of phyllo plane microbiota and has evolved to provide symbiotic protection (Argolo-Filho \& Leguercio et al. 2014). Research on B. thuringiensis has been actively done in order to make sure the safety of this bacterium in vertebrata. Wilcks et al. (2008) reported that $B$. thuringiensis was able to colonize in intestinal germ free of rats at high concentration in stable form but were eliminated through their feces with no effect found to the animals. The presence of $B$. thuringiensis in the rectal sample from dairy cow indicated that multiplication of $B$. thuringiensis cells had occurred in the digestive tract (Ammons (2009). Not only safety indication was shown by $B$. thuringiensis, but also its protection to the healthy gut. Kweon et al. (2012) found that B. thuringiensis contaminating in fresh milk was able to act as probiotic by preventing fatal infection of Escherichia coli 055, Salmonella typhimurium 01D and Staphylococcus aureus 305 in mice. B. thuringiensis also produced bacteriocin-like inhibitor substances (Bt-BLIS) with high level of activity against Bacillus cereus and other Gram positive bacteria such as Vibrio cholera (Barboza-Corona et al. 2007). Bacteriocins produced by $B$. thuringiensis was also able to inhibit growth of multiple antibiotic resistant bacteria associated with subclinical mastitis in dairy goats (Gutierrez-Cavez et al. 2015).

B. thuringiensis produce alkaline protease that showed proteolytic activity at various culture condition. The enzyme was active to hair substrate keratin and was used for de-hairing (Agastya et al. 2013). Recently, Zhang et al. (2015) identified and characterized a novel alkaline thermolysin like protease from $B$. thuringiensis with possible use in therapeutic and biotechnological application. Kent et al. (2012) reported that fermentation of sodium caseinate using $B$. thuringiensis resulting in Caseicin A and Caseicin B that identified previously by Hayes et al.. (2006) as antimicrobial peptide. B. thuringiensis isolate in this study from horse milk that showed highly active protease, as indicated by large clear zone when the bacterium was grown in the medium containing skim milk. The protease was used to hydrolyze Sumbawa horse milk protein to produce bioactive peptides. this paper disscuses proof of the potent antibacterial and antioxidant activities of bioactive peptide fraction.

\section{MATERIALS AND METHODS}

\section{Microorganisms}

B. thuringiensis was isolated from horse milk from Bogor, Indonesia. Escherichia coli (ATCC 25922), Salmonella Typhimurium (ATCC 13311) Listeria monocytogenes (ATCC 15313) and Staphylococcus aureus (ATCC 25923) were used for bacterial assays.

\section{Milk and enzyme preparation}

Horse milk was collected from Sumbawa Island, Indonesia. The milk was centrifuged at $6000 \times \mathrm{g}, 4^{\circ} \mathrm{C}$ for $15 \mathrm{~min}$ to discard the fat. Defatted milk was hydrolyzed immediately or stored at $-20^{\circ} \mathrm{C}$ until used. Protease was produced by culturing $B$. thuringiensis in Luria Bertani Broth (Difco, Becton Dickinson and Co, US) containing $0.05 \%(\mathrm{w} / \mathrm{v})$ skim milk (Difco, Becton Dickinson and Co, US) and incubated at $37{ }^{\circ} \mathrm{C}$ for $24 \mathrm{~h}$. The cells were separated by centrifugation $3500 \times \mathrm{g}$ for $20 \mathrm{~min}$. The crude enzyme was harvested by precipitation with cold $\left(4^{\circ} \mathrm{C}\right) 50 \%(\mathrm{w} / \mathrm{v})$ ammonium sulphate overnight and centrifuged at $10.000 \times \mathrm{g}, 4^{\circ} \mathrm{C}$ for $20 \mathrm{~min}$. The precipitate was air dried and stored at $20^{\circ} \mathrm{C}$ until used. For hydrolysis, crude enzyme was diluted in phosphate buffer saline $10 \mathrm{mM}$, pH 7.4 (1:2 $(w / v)$ ). Protein concentration was analyzed using Quick start ${ }^{\mathrm{TM}}$ Bradford protein assay (Bio-Rad Inc). Standard curve was obtained from reaction between $5 \mu \mathrm{L}$ of bovine serum albumin at serial dilution of $2.5-25 \mathrm{mg}$ $\mathrm{mL}^{-1}$ and $95 \mu \mathrm{L}$ Bradford solution. Deionized water was used as blank. Absorbance was measured at $\lambda 600 \mathrm{~nm}$ in microtiter plate reader (Labsystems, original Multiscan Ex, Champaign USA).

Enzyme activity assay was conducted according to Bergmeyer et al. (1983). Reaction was performed by mixing $250 \mu \mathrm{L}$ casein $2 \%(\mathrm{w} / \mathrm{v})$ with $50 \mu \mathrm{L}$ enzyme and $250 \mu \mathrm{L}$ PBS $0.05 \mathrm{M} \mathrm{pH} 7$ and incubated at $37^{\circ} \mathrm{C}$. As much as $500 \mu \mathrm{L}$ of TCA $0.2 \mathrm{M}$ (Sigma-Aldrich, USA) was added, incubated at $37^{\circ} \mathrm{C}$ for $10 \mathrm{~min}$ and then 
centrifuged at $2000 \times \mathrm{g}$ for $10 \mathrm{~min}$. As much as $375 \mu \mathrm{L}$ supernatant was mixed with $1250 \mu \mathrm{L} \mathrm{Na}_{2} \mathrm{CO}_{3} \quad 0,4 \mathrm{M}$ and $250 \mu \mathrm{L}$ reagent Folin ciolcateau (Sigma-Aldrich, USA) (1:2) and then incubated at $37^{\circ} \mathrm{C}$ for $20 \mathrm{~min}$. Optical density was measured at $\lambda 578 \mathrm{~nm}$ (spectrophotometer UV-Mini-1240 Shimadzu). One unit (IU) of enzyme was defined as the amount of enzyme needed to produce $1 \mu \mathrm{mol}$ tyrosin per min.

\section{Hydrolysis}

Horse milk was hydrolyzed by $B$. thuringiensis protease $(0.67 \mathrm{IU})$ with enzyme substrate ratio $1: 20$ (v/v). Hydrolysis was conducted at $55^{\circ} \mathrm{C}, \mathrm{pH} 11$ for 30 and $60 \mathrm{~min}$. The reaction was stopped in boiled water $95^{\circ} \mathrm{C}$ for $5 \mathrm{~min}$. Hydrolysates were centrifuged at $10.000 \times \mathrm{g}$ for $15 \mathrm{~min}$ to remove lipid and insoluble protein. The $\mathrm{pH}$ was adjusted to around 7. The supernatant was filtered using $0.45 \mathrm{~nm}$ membrane (Acrodisc LC $13 \mathrm{~mm}, 0.45 \mu \mathrm{m}$, PVDF, Pall Life Sciences, USA). Hydrolysate was sequentially filtered through membrane MWCO 30k, 10k and 3k (AMICON Ultra centrifugal units, Merck Millipore Ltd., Tullagreen, Carrigtwohill, Co). Retentate was diluted with the same volume of sterilized deionized water. Protein concentration of each fraction was determined using Quick start ${ }^{\mathrm{TM}}$ Bradford protein assay (Bio-Rad Laboratories Inc). All fractions were evaluated for antibacterial and antioxidant activities.

\section{Antibacterial assay}

Minimum Bactericidal Concentration (MBC) assay was performed according to Keepers et al. (2014) with modification. Briefly, $100 \mu \mathrm{l}$ of each peptide fraction was prepared in 2-fold dilution series in a 96-well round-bottom microplates. As much as $100 \mu \mathrm{l} S$ aureus, L monocytogenes, E. coli or S. typhimurium suspensions of $10^{6} \mathrm{CFU} \mathrm{mL} \mathrm{m}^{-1}$ was then added to the ependorf containing peptide fractions. Content of the well (100 $\mu \mathrm{l})$ was grown onto Mueller Hinton agar plate (BD Difco $^{\mathrm{TM}}$, Becton Dickinson and Co, USA) and incubated for $24 \mathrm{~h}$ at $37^{\circ} \mathrm{C}$. Additional $24 \mathrm{~h}$ incubation was done to ensure no bacterial growth. The MBC was recorded as the lowest concentration of the peptide fraction which produced no visible bacterial growth. Each treatment was done in three replications.

\section{Antioxidant assay.}

2,2'-azino-bis (3-ethylbenzthiazoline-6-sulphonic acid (ABTS) solution (Sigma-Aldrich, USA) was made according to Thaipong et al. (2006). The working solution was prepared by reaction of ABTS stock solution of $7.4 \mathrm{mM}$ and $2.6 \mathrm{mM}$ potassium persulphate and incubated for 18 hours at room temperature in the dark. The solution was diluted with deionized water to obtain an absorbance of $1.1 \pm 0.05$ at $405 \mathrm{~nm}$. The fresh ABTS was then used for antioxidant assay. Sample of $100 \mu \mathrm{L}\left(1 \mu \mathrm{g} \mathrm{mL}^{-1}\right)$ of each peptide fraction was mixed with $200 \mu \mathrm{L}$ ABTS in microplate and incubated at room temperature for $15 \mathrm{~min}$ to allow the reaction. Absorbance of the resulting mixture was recorded at $\lambda$ $405 \mathrm{~nm}$ using microplate reader (Labsystems, original Multiscan Ex, and Champaign, USA). The peptide control was made by substituting ABTS radical with deionized water, while ABTS control was made by substituting peptide fraction with deionized water. Serial concentrations of Vitamin C p.a (2.5-17.5 $\mu \mathrm{g} \mathrm{mL}^{-}$ ${ }^{1}$ ) was used as standard.

Antioxidant assay using 2,2-diphenyl-1picrylhydrazyl (DPPH) (Sigma-Aldrich, USA) was conducted by mixing ethanol $96 \%$ with DPPH to obtain absorbance $1.1 \pm 0.05$ at $\lambda=540 \mathrm{~nm}$. As much as $100 \mu \mathrm{L}$ of peptide fraction was added to $200 \mu \mathrm{L}$ DPPH. After incubation for $30 \mathrm{~min}$ at room temperature, the absorbance of the mixture was measured at $\lambda 540 \mathrm{~nm}$. Vitamin C p.a $(2-16 \mu \mathrm{g} / \mathrm{mL})$ was used for generating standard curve (Thaipong et al. 2006). The scavenging activity of peptide fractions to ABTS and DPPH radicals was expressed using equation:

\section{Scavenging activity $(\%)=100 \times(\mathrm{A} 0-\mathrm{A} 1) / \mathrm{A} 0$}

Where A0 was absorbance of ABTS/DPPH and A1 was the final absorbance of sample minus initial absorbance. Result from ABTS and DPPH assays was presented as means of experiments performed in three replications.

\section{Peptide profiling by RP-HPLC.}

Peptide fraction with highest antibacterial and antioxidant activities was run in reverse-phase high performance liquid chromatography (RP-HPLC). A preparative C-18 column $(25 \mathrm{~cm} \mathrm{x} 1.0 \mathrm{~cm}$ id); Xterra waters) was used with Hewlett-Packard 1050 series HPLC (Waters Corporation) equipped with diode array detector. Eluate was monitored at $215 \mathrm{~nm}$. The solvents consisted of: (A) $0.1 \%$ (v/v) trifluoroacetic acid (TFA) (Sigma-Aldrich, USA) in deionized water and (B) $0.1 \%$ (v/v) TFA in acetonitrile (Sigma-Aldrich, USA), flow rate $1 \mathrm{~mL} / \mathrm{min}$. The HPLC system was equilibrated with 95\% solvent A for $5 \mathrm{~min}$, followed by linear gradient of $5-45(\mathrm{v} / \mathrm{v})$ solvent B over $15 \mathrm{~min}$ to elute peptide and a 5 min re-equilibration.

\section{SDS-PAGE analysis}

Peptide profile from the 30 and 60 min hydrolysis was analyzed by sodium dodecyl sulphatepolyacrylamide gel electrophoresis (SDS-PAGE) by using precast gradient polyacrylamide gel 
electrophoresis $4-20 \%$ (Any $\mathrm{kD}^{\mathrm{TM}}$ Mini-Protean ${ }^{\circledR} \mathrm{TGX}$ gel, Bio-Rad Laboratories Inc.) with coomassie blue staining (Sigma-Aldrich, USA).

\section{Hemolysis assay}

Hemolysis assays were performed using experimental procedure described by Lorenzon et al. (2012) and Nguyen et al. (2011). Freshly prepared chicken red blood cells (RBCs) were washed three times with $0.01 \mathrm{M}$ Tris- $\mathrm{HCl}(\mathrm{pH} 7.4)$ containing $0.15 \mathrm{M}$ $\mathrm{NaCl}$ (Tris-saline). A suspension of $1 \% \quad(\mathrm{v} / \mathrm{v})$ erythrocytes was made by re-suspending cells in Trissaline. A $100 \mu$ peptide $\left(0.1 \mathrm{mg} \mathrm{mL}^{-1}\right)$ was added with $100 \mu \mathrm{RBCs}$, incubated for $1 \mathrm{~h}$, at $37^{\circ} \mathrm{C}$. The samples were centrifuged at $3000 \times \mathrm{g}$ for $5 \mathrm{~min}$. A $100 \mu \mathrm{l}$ of the supernatant was transferred to 96-well microplate and the absorbance was determined at $540 \mathrm{~nm}$. The assay was performed in triplicate. A $1 \%$ Triton X-100 (Sigma-Aldrich, USA) solution was used as positive control (100\% lysis) and Tris-saline as a negative control.

\section{Peptide sequencing}

Peptide samples were trypsin digested and extracted according to standard procedures (Bringans et al. 2007). Peptides were analyzed by electrospray ionisation mass spectrometry using the Agilent 1260 Infinity HPLC system [Agilent] coupled to an Agilent 6540 mass spectrometer [Agilent]. Tryptic peptides were loaded onto a C18 column $300 \mathrm{SB}, 5 \mathrm{~cm}$ [Agilent] and separated with a linear gradient of water/acetonitrile/ $0.1 \%$ formic acid $(\mathrm{v} / \mathrm{v})$. Spectra were analysed to identify proteins of interest using Mascot sequence matching software [Matrix Science] with Ludwig NR database.

\section{Peptide analysis}

Calculation of theoretical properties and primary structure were conducted using primary structure analysis www.expasy.org and possibility to antimicrobial peptide was analyzed using http://aps.unmc.edu/AP/prediction/prediction_main.php , therapeutic index was analyzed using http://split4.pmfst.hr/split/dserv1/?akcija=run, peptides structure predicted using http://bioserv.rpbs.univ-parisdiderot.fr/PEP-FOLD/ (Maupetit et al. 2009; Maupetit et al. 2010; Thevenet et al. 2012; Shen et al 2014) and and RasWin Molecular Graphic (http//www.rasmol.org), therapeutic index was analyzed using http://split4.pmfst.hr/split/dserv1/?akcija=run (Juretic et al. 2009).

\section{RESULTS AND DISCUSSION}

\section{Antibacterial activities}

The peptides produced from horse milk protein hydrolysis were fractionated into fraction $>30,10-30,3-$ 10 and $<3 \mathrm{kDa}$. The antibacterial activities of those fractions was shown in Table 1 . The minimum bactericidal concentration (MBC) of the peptides before fractionation was much higher compared to after fractionation. Result revealed that fractionation based on the size was able to separate, concentrate the active peptides and improve the antibacterial properties. From all fractions, fraction $<3 \mathrm{kDa}$ has the highest antibacterial activity as it has the lowest MBC value, especially for E. coli and S. Typhimurium.

The result showed that minimum bactericidal concentration (MBC) fraction $<3 \mathrm{kDa}$ from the 30 and 60 min hydrolysis was similar, suggesting that $30 \mathrm{~min}$ was sufficient time to produce potent antibacterial peptide. Fraction $<3 \mathrm{kDa}$ in this study was better in killing Gram negative bacteria, E.coli and $S$. typhimurium than Gram positive bacteria, $S$. aureus and L. monocytogenes. Similar result reported by Kent et al (2012) who found that fraction $<5 \mathrm{kDa}$ yielding from casein hydrolyzed by $B$. thuringiensis protease contain peptide Caseicin A and Caseicin B which were active to Gram-negative bacterium, Cronobacter sakazakii.

Table 1. Minimum bactericidal concentration of peptide fractions

\begin{tabular}{|c|c|c|c|c|c|c|c|c|c|c|}
\hline \multirow{5}{*}{$\begin{array}{l}\text { Indicator } \\
\text { microorganisms }\end{array}$} & \multicolumn{10}{|c|}{ Minimum bactericidal concentration of peptide fractions $\left(\mathrm{mg}\right.$ protein $\left.\mathrm{mL}^{-1}\right)$} \\
\hline & \multirow{4}{*}{$\begin{array}{l}\text { Before } \\
\text { Fractio- } \\
\text { nation }\end{array}$} & \multicolumn{5}{|c|}{$30 \mathrm{~min}$ hydrolysis } & \multirow{2}{*}{\multicolumn{4}{|c|}{$\begin{array}{l}60 \text { min hydrolysis } \\
\text { After fractionation }\end{array}$}} \\
\hline & & \multicolumn{4}{|c|}{ After fractionation } & \multirow{3}{*}{$\begin{array}{l}\text { Before } \\
\text { fractio- } \\
\text { nation }\end{array}$} & & & & \\
\hline & & $>30$ & $10-30$ & $3-10$ & $<3$ & & $>30$ & $10-30$ & $3-10$ & $<3$ \\
\hline & & $\mathrm{kDa}$ & $\mathrm{kDa}$ & $\mathrm{kDa}$ & $\mathrm{kDa}$ & & $\mathrm{kDa}$ & $\mathrm{kDa}$ & $\mathrm{kDa}$ & $\mathrm{kDa}$ \\
\hline S. aureus & $>10$ & $>0.14$ & $>0.14$ & $>0.14$ & $>0.14$ & $>10$ & $>0.14$ & $>0.14$ & $>0.14$ & $>0.14$ \\
\hline L. monocytogenes & 10 & 0.14 & 0.07 & 0.14 & 0.14 & 10 & 0.14 & 0.14 & 0.14 & 0.14 \\
\hline E. coli & 10 & 0.14 & 0.07 & 0.14 & 0.035 & 5 & 0.14 & 0.07 & 0.14 & 0.035 \\
\hline S. typhimurium & 10 & 0.07 & 0.07 & 0.14 & 0.035 & 10 & 0.14 & 0.07 & 0.14 & 0.035 \\
\hline
\end{tabular}




\section{Antioxidant activities}

Two antioxidant assays used in this study were 2,2azinobis (3-ethylbenzothiazoline-6-sulfonic acid) (ABTS) and 2,2-diphenyl-1-picrylhydrazyl (DPPH). Scavenging activities of the peptides were determined by reduction of ABTS or DPPH absorbance after addition of peptide. Under the assay condition, $100 \%$ of scavenging activity correspond to complete scavenging of ABTS or DPPH radical. Scavenging activities to ABTS and DPPH radicals varied among the peptide fractions (Figure 1). Generally, peptide from the 30 minutes hydrolysis scavenged the ABTS radical better than the $60 \mathrm{~min}$ hydrolysis. Peptides from the $30 \mathrm{~min}$ hydrolysis, fraction $<3 \mathrm{kDa}$, had the best antibacterial activity and also high scavenging activity $(82 \%)$, almost similar to the scavenging activity of $12.5 \mu \mathrm{g} \mathrm{mL}-1$ vitamin $\mathrm{C}(84 \%)$. As in antibacterial assay, fractionation increased scavenging activities to the ABTS radicals. However, it seems that size might not be important factor for the activities. For example, fraction $10-30 \mathrm{kDa}$ for 30 and $60 \mathrm{~min}$ hydrolysis scavenged ABTS radical better than fraction 3-10 kDa.

For DPPH assay, the highest scavenging activity was shown by fraction $<3 \mathrm{kDa}$ from the $60 \mathrm{~min}$ hydrolysis (57\%) (Fig. 1) almost similar to $14 \mu \mathrm{g} \mathrm{mL}^{-1}$ vitamin $\mathrm{C}(58 \%)$. Fraction $10-30 \mathrm{kDa}$ from $60 \mathrm{~min}$ hydrolysis which has high activity in ABTS assay was only able to scavenge DPPH radical by $49 \%$. The fraction whose good antibacterial and scavenging ABTS radical activity, fraction $<3 \mathrm{kDa}$ from the $30 \mathrm{~min}$ hydrolysis, scavenged DPPH radical by $22 \%$. Different from that of ABTS assay, in DPPH assay, peptide from the $60 \mathrm{~min}$ hydrolysis resulted in better scavenging activity compared to that from 30 min hydrolysis.

The radical scavenging activities were assessed with the lipid soluble DPPH radical as well as the water soluble ABTS radical (Damgaard et al. 2014). The ABTS or DPPH assay is based on the ability of antioxidant to transfer electron or donate hydrogen atom to the radicals which result in a color change and reduce the absorbance. Generally, good scavenging activity to ABTS radical was obtained from the $30 \mathrm{~min}$
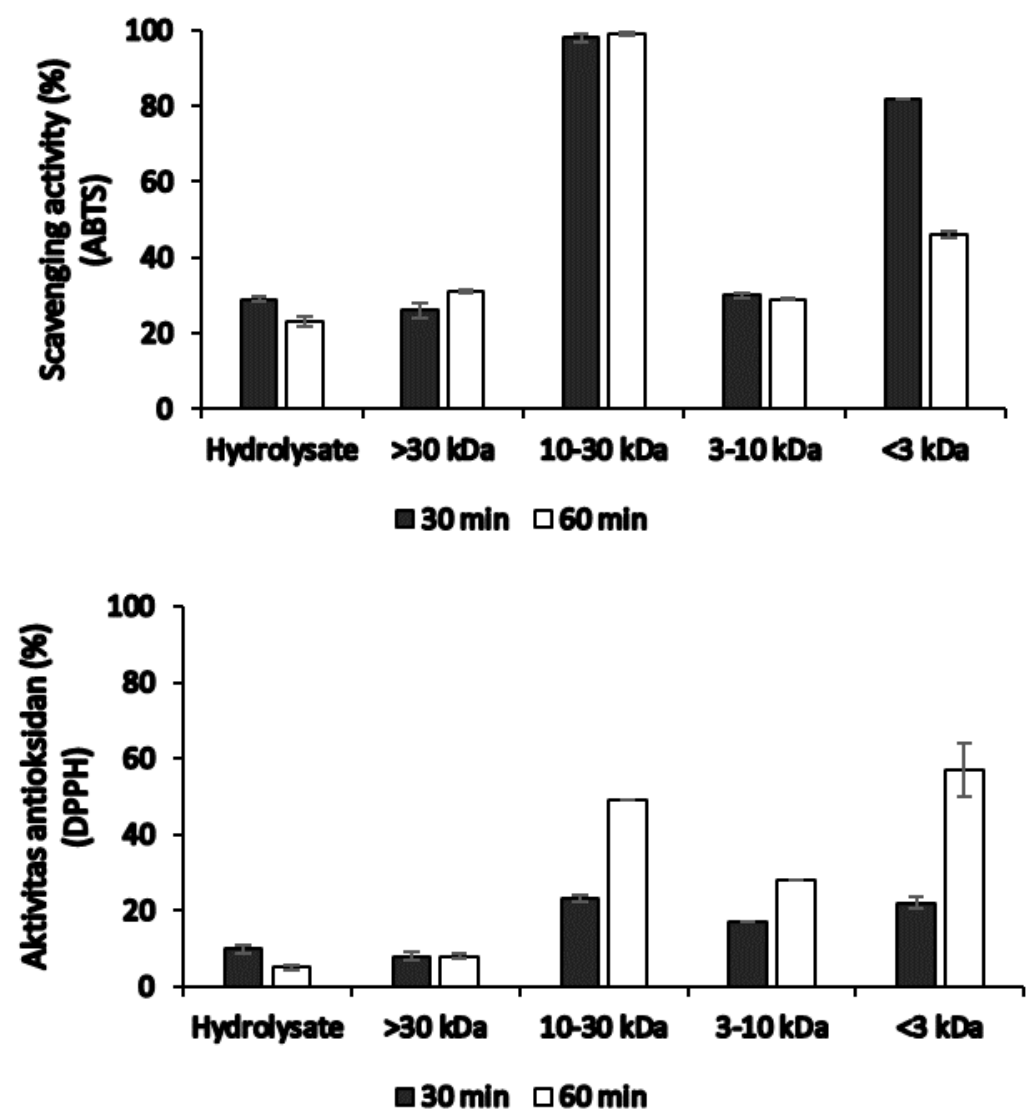

Figure 1. Scavenging activities of peptide before and after fractionation using membrane molecular cut off 30,10 and $3 \mathrm{kDa}$ against ABTS and DPPH radicals per $\mu \mathrm{g}$ protein $\mathrm{mL}^{-1}$. Value represent the mean \pm standard deviation (SD). 
hydrolysis peptide, while that of DPPH was obtained from the $60 \mathrm{~min}$ hydrolysis peptide. The result indicated that the time of hydrolysis is determinant to scavenging activities. Amza et al. (2013) reported that hydrolysis of gingerbread plum (Neocarya macrophylla) more than 30 min decreased scavenging activity to DPPH radicals. Hydrolysis of ovine milk using protease Bacillus sp. P7 showed that antioxidant activity measured by ABTS method increased up to $2 \mathrm{~h}$ hydrolysis and stable for up to $4 \mathrm{~h}$. (Correa et al. 2011). In addition, enzyme substrate ratio must also take into consideration along with hydrolysis time which determine hydrophobic and aromatic amino acid content in the peptide sequence produced which will affect the antioxidant capacity (Gao et al. 2014).

The result of ABTS and DPPH assay showed that scavenging activity and their mechanism were slightly different due to the difference of sensitivity and mechanism of action of ABTS and DPPH assay. DPPH was performed in organic solvent, thus is more suitable for lipophilic antioxidant compound whereas ABTS is compatible with both aqueous and organic system (Prior et al. 2005). It is possible that peptide hydrolysate generated from the $60 \mathrm{~min}$ hydrolysis contain more lipophilic peptides than the peptides from $30 \mathrm{~min}$ hydrolysis.

\section{Hemolysis activities}

Hemolysis assay is a simple method to evaluate possible toxicity of the active peptide to eukaryote cells. In spite of the many promising bioactive peptide, some may be cytotoxic to eukaryotic cells which hampered the peptide application. Expectation for antibacterial peptide application is that the peptide is able to kill pathogenic bacteria but does not harm eukaryotic cell. In this study, fraction $10-30 \mathrm{kDa}$ had sufficient antibacterial and antioxidant activities but high in their hemolysis activity (17.21 and 17.28\%) (Figure 2). Fraction $<3 \mathrm{kDa}$ which possess high antibacterial and antioxidant activities peptide demonstrated low hemolysis activity (2.27 and 2.26\%) which indicate safety application. Thus, fraction $<3 \mathrm{kDa}$ was more promising as this fraction is highest in antibacterial activity and good antioxidant activity, but low in hemolysis activity.

\section{Peptide profiling in RP-HPLC}

Profiling of the fraction $<3 \mathrm{kDa}$ using RP-HPLC resulted in the chromatogram with major peaks as shown in Figure 3 at the hydrophobic condition. Peptide with retention time $\left(R_{t}\right) 9.5$ and 10 min were more hydrophobic as they were eluted in the hydrophobic mobile phase. Kim et al. (2005) demonstrated that hydrophobicity as indicated by the retention time is better related to the antimicrobial activity than hydrophobic calculation from the sequence analysis.

Based on the HPLC chromatogram, peptides from fraction $<3 \mathrm{kDa}$ appeared as a mixture of hydrophilic and hydrophobic molecules. Hydrophobicity and retention time in HPLC chromatogram of peptide may correlate with antimicrobial peptide activity. Nielsen et al. (2007) found that the compound with longest HPLCretention time showed best minimum inhibitory concentration (MIC). They also reported that HPLC retention time is a better parameter for antibacterial activity than hydrophobicity and hydrophobic moment alone. Peptides with higher hydrophobicity on their nonpolar face generally showed stronger selfassociating ability in solution, since dimers can be formed by interactions between the nonpolar faces of two molecules (Chen et al. 2007). Peptide with less hydrophobic in HPLC data has a weaker tendency to aggregate in aqueous solution and that it has lower propensity for interaction with hydrophobic surface than hydrophobic peptide (Abraham et al. 2014). Hydrophobicity of the peptides as indicates by HLPC retention time data also correlated well the activity

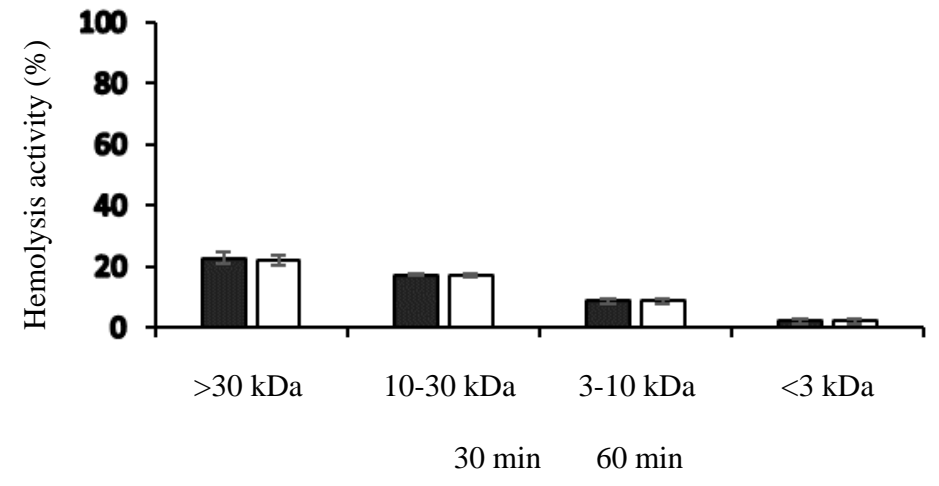

Figure 2. Hemolysis activities of peptide $\left(0.1 \mathrm{mg}\right.$ protein $\left.\mathrm{mL}^{-1}\right)$ before and after fractionation using membrane molecular cut off 30 , 10 and $3 \mathrm{kDa}$. Value represent the mean \pm standard deviation (SD). 

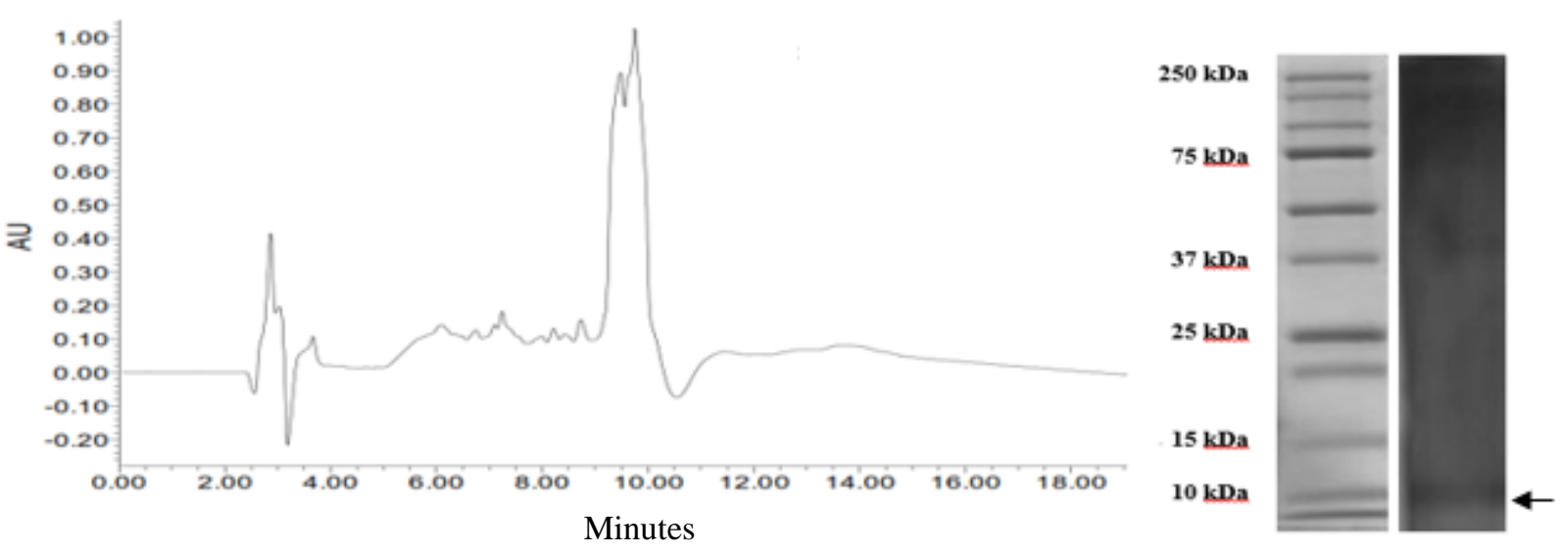

Figure 3. Profile of peptide fraction $<3 \mathrm{kDa}$ in HPLC chromatogram and SDS PAGE.

against artificial membrane and Gram positive bacterial species such as Staphylococcus aureus, Staphylococcus epidermidis and Micrococcus luteus rather than mean hydrophobicity that obtained from simple calculation of hydrophobicity of each constituent amino acid. Even though there are cases where antimicrobial activity against Gram negative bacteria such as Escherichia coli did not show correlation with analysis of HPLC retention time (Kim et al. 2005).

The fraction $<3 \mathrm{kDa}$ was detected in higher molecular weight in electrophoresis gel (around 10 $\mathrm{kDa}$ ) (Fig 3), the peptides may form oligomer. Banerjee et al. (2015) reported that oligomer form of antibacterial peptide purified from hearth of Capra hircus was detected in electrophoresis gel. Some of antimicrobial peptides are able to form oligomer or supramolecular in the presence or without sodium dodecyl sulfate. Antimicrobial peptides generally adopted disordered structures and the presence of proline affect the supramolecular arrangement in peptide solution (Vermeer et al. 2012), beside possibility to form self-aggregation and protein or peptide association (Monteiro et al. 2015).

Oligomerization of antimicrobial peptide in lipid membrane are vital for their mode of action. Monomer or oligomer form of the bioactive peptide was reported of capable to affect the way of peptide insert to surface of target cells. Saravan and Bhattacharjya (2011) demonstrated that replacement of Tyr to Ala showed lack of oligomerization and reduced antibacterial activity of peptide VK22AA, a peptide derived from fowlicidin-1 and cathelicidin, a family of antimicrobial peptide from chicken. The tetrameric structure was stable and embedded into zwitterionic phosphocholine micelles such that the non-polar region is located inside the lipid acyl chains while the monomer form is localized at the surface of the micelles. Bai et al. (2012) reported that branched peptides (oligomer) have been shown considerable advantages over their monomeric form such as improved antimicrobial activity, maintaining high efficacy under physiological condition, enhanced bacterial surface binding affinity, decreased susceptibility to proteolytic degradation and low toxicity. The oligomer form, in case of protegrin antimicrobial peptide, increased stability and antimicrobial activity as well as cytotoxicity. Protegrin monomer interacts very weakly with the surface of zwitterionic membranes but absorbed well on the surface of anionic membrane, but oligomer could insert forming pores into both anionic and zwitterionic mamalian membrane (Lazaridis et al. 2013).

This phenomenon of higher molecular weight in electrophoresis gel may also explain the presence of anomalous SDS-PAGE migration of peptide due to peptide-peptide interaction and peptide-SDS interaction. Rath et al. (2009) found that hydropathy and helicity were able to cause gel shifting that produce slower migration which should not be considered as indicator of oligomeric state, compactness and degree of foldedness.

\section{Peptides analysis}

After tryptic digestion, analysis using Mascot software revealed that the peptides fraction composed of 13 tryptic peptides with molecular mass calculation of 921.48 - 1954.95 Da (Table 2).

The hydrophobicity of the peptides is 11.26-17.98 $\mathrm{kcal} / \mathrm{mol}$. Grau-Campistany et al. (2015) found that formation of transmembrane pores is only possible under the condition of hydrophobic matching: the peptide have to be a long enough to span the hydrophobic bilayer core to be able to induce vesicle leakage and kill the bacteria. Rosenfeld et al. (2010) reported that increasing the ratio between 
Table 2. Physio-chemical properties of the possible peptide from fraction $<3 \mathrm{kDa}$

\begin{tabular}{|c|c|c|c|c|c|c|}
\hline Peptide identified & Length & Mass (Da) & PI & Net charge & $\begin{array}{l}\text { Hidrophobicity } \\
\text { (kcal/mol) }\end{array}$ & $\begin{array}{c}\text { Therapeutic } \\
\text { index }\end{array}$ \\
\hline LVNELTEFAK & 10 & 1162.62 & 4.09 & -1 & 14.89 & 28.69 \\
\hline YLYEIAR & 7 & 926.48 & 6.48 & 0 & 10.50 & 27.43 \\
\hline HPYFYAPELLYYANK & 15 & 1887.92 & 7.47 & 0 & 11.74 & 64.75 \\
\hline AEFVEVTK & 8 & 921.48 & 4.09 & -1 & 16.08 & 6.40 \\
\hline DAIPENLPPLTADFAEDK & 18 & 1954.95 & 3.39 & -4 & 26.57 & 6.60 \\
\hline DAFLGSFLYEYSR & 13 & 1566.73 & 4 & -1 & 12.21 & 10.57 \\
\hline RHPEYAVSVLLR & 12 & 1438.80 & 9.53 & +1 & 14.45 & 5.53 \\
\hline HPEYAVSVLLR & 11 & 1282.70 & 7.50 & 0 & 12.64 & 6.28 \\
\hline HLVDEPQNLIK & 11 & 1306.71 & 5.19 & -1 & 17.98 & 9.58 \\
\hline LGEYGFQNALIVR & 13 & 1478.79 & 6.49 & 0 & 11.26 & 8.36 \\
\hline KVPQVSTPTLVEVSR & 15 & 1638.93 & 9.77 & +1 & 15.52 & 5.90 \\
\hline VPQVSTPTLVEVSR & 14 & 1510.83 & 6.51 & 0 & 12.72 & 8.14 \\
\hline KQTALVELLK & 10 & 1141.70 & 9.63 & +1 & 14.44 & 7.33 \\
\hline
\end{tabular}

hydrophobicity and the net positive charge increased both antimicrobial and bacterial lipopolysaccharide neutralization activities. Whereas antimicrobial activity increases linearly with the increase in the peptides hydrophobicity, peptides with different hydrophobicity are endowed with similar LPS neutralizing activities. Hydrophobicity side chain of peptide determined optimization of membrane selectivity or antibacterial potency (Henriksen et al. 2014). Bahnsen et al. (2013) added that charge and hydrophobicity alone cannot account for antimicrobial and cytotoxicity activities, but also influenced by conformational and secondary structure of peptide. It is important to maintain certain content of amphipathic secondary structure for a desirable biological activity (Mai et al. 2015).

Fraction $<3 \mathrm{kDa}$ from the $30 \mathrm{~min}$ hydrolysis were dominated by neutral and negatively charge peptides. Although antimicrobial peptide is commonly being cationic in nature, a number of anionic antimicrobial peptides have been reported, serving as important weapons in eukaryote innate immune system. Similar to their cationic counterpart, anionic antimicrobial peptides can adopt varying amphiphilic structure such $\alpha$-helix and $\beta$-sheet conformations with interaction with the membrane key to activity (Laverty et al. 2011).

Beside hydrophobicity and peptide charge, amino acid composition of a peptides affects antimicrobial activity. Bahnsen et al. (2013) revealed that Arg in the peptide sequence is important as a presence of multiple guanidium groups facilitated both uptake and enhances antimicrobial activity. Amino acid composition also related to physicochemical properties of the peptide that would affect the activity. Change amino acid composition from GS10 [cyclo-(VKLdYPVKLdYP)], a synthetic analog of the naturally occurring antimicrobial peptide gramicidin (GS) in which the two positively charged ornithine (Orn) residues are replaced by two positively charged lysine (Lys) residues and the two less polar aromatic phenylalanine (Phe) residues are replaced by the more polar tyrosine (Tyr) residues, increased aqueous solubility and changed physicochemical properties and its capacity with both model and biological membrane (Abraham et al. 2014).

The peptide with the highest therapeutic index (TI) prediction to $E$. coli in our study, is HPYFYAPELLYYANK with TI=64.75. Although the charge of peptide HPYFYAPELLYYANK was neutral, the TI prediction was higher than previous report positively charges antimicrobial peptides, Casecidin 15, YQEPVLGPVRGPFPI with TI: 9.17 and Casecidin 17, YQEPVLGPVRGPFPIIV with TI: 11.98. Both casecidin 15 and Casecidin 17 have MIC value to $E$. coli DPC6053, $0.4 \mathrm{mg} \mathrm{mL}-1$. TI is calculated from ratio $50 \%$ hemolytic activity (HC50) to minimum inhibitory concentration (MIC). Unfortunately, the information about hemolytic activity of both Casecidin 15 and Casecidin 17 are not available. More comprehensive data was revealed by peptide Piscidin and its substitution of hydrophobic amino acid. D-Piscidin 1 (FFHHIFRGIVHVGKTIHRLVTG) with TI prediction to $E$. coli 7.54 showed experimental hemolytic activity (HC50) and MIC were $1.8 \mu \mathrm{M}$ and $2.8 \mu \mathrm{M}$ respectively with TI to Acinetobacter baumannii was 0.6. Replacement of I at 9th amino acid to $\mathrm{K}$ (FFHHIFRGKVHVGKTIHRLVTG) with TI prediction to $E$. coli 9.44 showed experimental hemolytic activity 

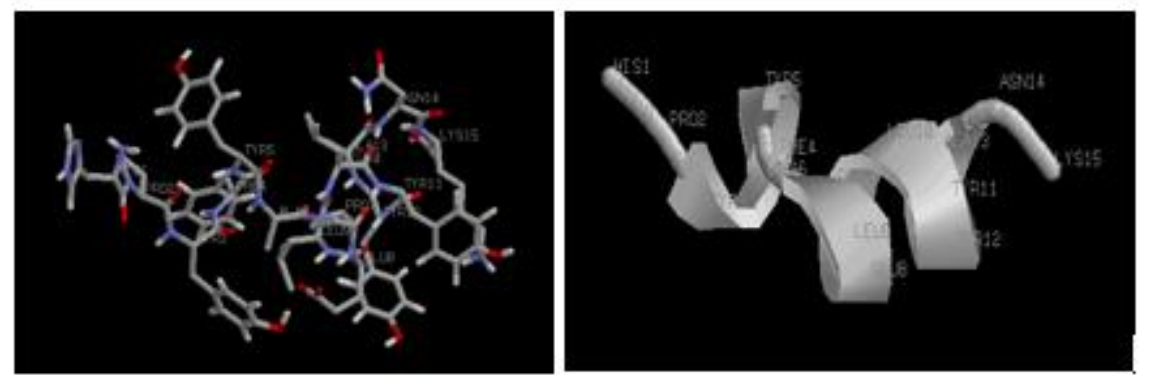

Figure 4. Predicted structure of the peptide from fraction HPYFYAPELLYYANK, TI: 64.75.

(HC50) and MIC were $98 \mu \mathrm{M}$ and $3.0 \mu \mathrm{M}$ respectively and TI to Acinetobacter baumannii was 33 (Jiang et al. 2014). Case of Piscidin showed that TI prediction was sufficiently accurate for antimicrobial activities prediction. Although we have not synthesized and examined the activity of peptide HPYFYAPELLYYANK alone, the peptide is promising to be antimicrobial peptide as TI prediction was 64.75 and higher than other reported peptides.

Although peptide HPYFYAPELLYYANK showed high in TI prediction but the peptide has not been confirmed as antibacterial activity determinant in the fraction $<3 \mathrm{kDa}$. Interaction among peptide in the fraction may decrease or enhance the antibacterial activity. Hayes et al. (2006) reported that antimicrobial activity was not detected in casein fermented by Lactobacillus acidophilus before fractionation. Electrostatic interaction between charged peptides may have a negative effect to antimicrobial activity of the fermentate. On the contrary, Rahnamaeian et al. (2015) demonstrated that combination of two antimicrobial peptides from bumblebee, hymenoptaecin and abaecin resulting in a more potent effect at low concentration.

\section{Peptide structure prediction}

Structure prediction of the peptide HPYFYAPELLYYANK with high therapeutic index was in Figure 4. Structure prediction showed that peptide peptide HPYFYAPELLYYANK is able to form helix that important for antimicrobial activity (Fig. 4). Multiple studies demonstrated that helicity is important for toxicity, antimicrobial activity (Huang et al 2010) and interfacial binding (Fernandez-Vidal, 2007) beside physicochemical parameter such as hydrophobicity amphipaticity, charge and sequence.

\section{CONCLUSION}

B. thuringiensis that commonly contaminate milk was a source of protease enzyme which can be used to produce antibacterial and antioxidant peptide from horse milk. Time of hydrolysis, separation and processes are important in generating the desirable bioactive peptide. Considering safety of the peptide, sequentially filtrations were needed to obtain high activity and safe peptide. Fraction $<3 \mathrm{kDa}$ from the 30 min hydrolysis was safe fraction with good in antibacterial and antioxidant activities. The fraction consists of 13 peptides variety in physicochemical properties. Peptide HPYFYAPELLYYANK has the highest therapeutic index and potent to be antimicrobial peptide.

\section{ACKNOWLEDGEMENT}

This workwas supported by grant from Directorate General of Higher Education, Ministry of Education and Culture, Indonesia BOPTN scheme No 2013.089.521219, 2013, Ministry of Agriculture, Indonesia APBN No 18023D, 2014 and No 1806.105.002.052A, 2016

\section{REFERENCES}

Argolo-Filho RC, Loguercio LL. 2014. Bacillus thuringiensis is an environmental pathogen and host-specificity has developed as an adaptation to human-generated ecological niches. Insect. 5:62-91.

Abraham T, Prenner EJ, Lewis RNAH, Mant CT, Keller S, Hodges RS, Melhaney RN. 2014. Structure-activity relationships of the antimicrobial peptide gramicidin $S$ and its analogs: Aqueous solubility, self-association, conformation, antimicrobial activity and interaction with model lipid membranes. Biochimica et Biophysica Acta. 1838:1420-1429.

Agastya AS, Sharma N, Mohan A, Mahal P. 2013. Isolation and molecular characterization of alkaline protease producing Bacillus thuringiensis. Cell Biochem Biophys. 66:45-51.

Ammons DR. 2009. An investigation of Bacillus thuringiensis in rectal-collected fecal samples of cows. Curr Microbiol. 59:532-536. 
Amza T, Balla A, Tounkara F, Man L, Zhou HM. 2013. Effect of hydrolysis time on nutritional, functional and antioxidant properties of protein hydrolysates prepared from gingerbread plum (Neocarya macrophylla) seeds. Int Food Res J. 20:2081-2090.

Bahnsen JS, Franzyk H, Sandberg-Schaal A, Nielsen HM. 2013. Antimicrobial and cell-penetrating properties of penetratin analogs: Effect of sequence and secondary structure. Biochemica et Biophysica Acta. 1928:223232.

Bai Y, Liu S, Li J, Laksminarayan R, Sarawathi P, Tang C, Ho D, Verma C, Beuerman RW, Pervushin K. 2012. Progressive structuring of a branced antimicrobial peptide on the path to inner membrane target. J Biol Chem. 287(32): 26606-26617.

Banerjee D, Gohil T, Trivedi S. 2015. Antibacterial activity of oliomeric $\beta$-defensin isolated from heart tissue of Capra hircus. Int J Pharm Sci. 7:131-135.

Barboza-Corona, JE, Vazquez-Acosta H, Bideshi DK, Salcedo-Hernandez R. 2007. Bacteriocin-like inihibitor substances produced by Mexican strains of Bacillus thuringiensis. Arch Microbiol. 187:117-126.

Bergmeyer HU, Bergmeyer J, Grassl M. 1983. Methods of enzymatic analysis. Vol 2. Weinheim: Verlag Chemie, Weinheim, Germany.

Chen Y, Guarnieri MT, Vasil AI, Vasil ML, Mant CT, Hodges RS. 2007. Role of peptide hydrophobicity in the mechanism of action of $\alpha$-helical antimicrobial peptide, Antimicrob Agent Chemother. 51:1398-1406..

Correa AP, Daroit DJ, Coelho J, Meira SM, Lopes FC, Segalin J, Risso PH, Brandelli A. 2011. Antioxidant, antihypertensive and antimicrobial properties of ovine caseinate hydrolyzed with microbial protease. J Sci Food Agric. 91:2247-2254.

Damgaard TD, Otte JAH, Meinert L, Jensen K, Lametsch R. 2014. Antioxidant capacity of hydrolyzed porcine tissues. Food Sci Nutr. 2:282-288.

Detha A, Sudarwanto M, Latif H, Datta FU, Rahayu P. 2013. Fractionation and identification antimicrobial activity of Sumbawa mare milk protein against causative agent of subclinical mastitis. Global Vet. 11:674-668.

Domnez N, Kisadere I, Balaban C, Kadiralieva N. 2014 Effect of traditional homemade koumiss on some hematological and biochemical characteristics in sedentary men exposed to exercise. Biotech Histochem. 89:1-6.

Fernandez-Vidal M, Jayasinghe S, Ladokhin AS, White SH. 2007. Folding amphipathic helices into membranes: Amphiphilicity trumphs hydrophobicity. J Mol Biol. 370:459-470.

Frederiksen K, Rosenquist H, Jergensen K, Wilcks A. 2006. Occurrence of natural Bacillus thuringiensis contaminants and residues Bacillus thuringiensis-based insecticides on fresh ffruits and vegetables. Appl Environ Microbiol. 72:3435-3440.
Gao Q, Smith JC, Tsopmo A. 2014. Optimized protamex digested oat brand proteins: Antioxidant properties and identification of new peptides. Austin J Nutri Food Sci. 2:1-6.

Grau-Campistany A, Strandberg E, Wadhwani P, Reinchert J, Burk J, Rabana F, Ulrich AS. 2015. Hidrophobic mismatch demonstrated for membranolytic peptides, and their use as molecular rulers to measure bilayer thickness in native cells. Sci Rep. 5:9388.

Gutierrez-Chavez AJ, Martinez-Ortega EA, Valencia-Posadas M, Leon-Galvan MF, de la Fuente-Salcido NM, Bideshi DK, Barboza-Corona JE. 2015. Potential use of Bacillus thuringiensis bacteriocin to control antibiotic-resistant bacteria associated with mastitis in dairy goat. Folia Microbiol [Epub ahead of print].

Hayes M, Ross RP, Fitzgerald GF, Hill C, Stanton C. 2006. Ceasein-derived antimicrobial peptides generated by Lactobacillus acidophilus DPC6026. Appl Environ Microbiol. 72:2260-2264.

Henriksen JR, Etzerodt T, Gjetting T, Andresen TL. 2014. Side chain hydrophobicity modulates therapeutic activity and membrane selectivity of antimicrobial peptide mastoparan-X. PLoS ONE. 9:e91007.

Huang Y, He L, Li G, Zhai N, Jiang H, Chen Y. 2014. Role of helicity of $\alpha$-helical antimicrobial peptides to improve specificity. Protein Cell. 5:631-642.

Huang YH, Huang JH, Chen Y. 2010. Alpha-helical cationic antimicrobial peptides: relationships of structure and function. Protein Cell. 1:143-152.

Jiang Z, Vasil AI, Vasil ML, Hodges RS. 2014. "Specificity determinants" improve therapeutic indices of two antimicrobial peptides piscidin 1 and dermaseptin S4 againts the Gram-negative pathogens Acinetobacter baumannii and Pseudomonas aeruginosa. Pharmaceuticals. 7:366-391.

Juretic D, Vukicevic D, Ilic N, Antcheva N, Tossi A. 2009. Computational design of high selective antimicrobial peptides. J Chem Inf Model. 49:2873-2882.

Keepers TR, Gomez M, Celeri C, Nichols WW, Krause KM. 2014. Bactericidal activity, absence of serum effect and time-kill kinetics of Ceftazidime-Avibactam against $\beta$ lactamase-producing Enterobacteriaceae and Pseudomonas aeruginosa. Antimicrob Agents Chemother. 58:5297-5305.

Kent RM, Guinane CM, O'Connor PM, Fitzgerald GF, Hill C, Stanton C, Ross RP. 2012. Production of the antimicrobial peptides Caseicin A and B by Bacillus isolates growing on sodium caseinate. Lett Appl Microbiol. 55:141-148.

Kim S, Kim SS, Lee BJ. 2005. Correlation between the activities of alpha-helical antimicrobial peptides and hydrophobicities represented as RP HPLC retention time. Peptides, 2050-2056.

Kweon C, Choi S, Kwon H, Kim E, Kang H, Moon J, Jang G, Lee H, Kang S, Kim J. 2012. Isolation, characterization, 
and evaluation of Bacillus thuringiensis isolated from cow milk. Korean J Vet Res. 52:169-176.

Laverty G, Gorman SP, Gilmore BF. 2011. The potential of antimicrobial peptides as biocides. Int $\mathbf{J}$ Mol Sci. 12:6566-6596.

Lazaridis T, He Y, Prieto L. 2013. Membrane interaction and pore formation by the antimicrobial peptide protegrin. Biophys J. 104:633-642.

Lorenzon EN, Cespedes GF, Vicente EF, Nogueira LG, Bauab TM, Castro MS, Cilli EM. 2012. Effect of dimerization on the structure and biological activity of antibacterial peptide Ctx-a. Antimicrob Agents Chemother 56, 3004-3010.

Mai XT, Huang J, Tan J, Huang Y, Chen Y. 2015. Effects and mechanisms of secondary structure on the antimicrobial activity and specificity of antimicrobial peptides. J Pept Sci. 7:561-568.

Maupetit J, Derreumaux P, Tuffery P. 2009. PEP-FOLD: an online resource for de novo peptide structure prediction. Nucleic Acids Res. 37: W498-503.

Maupetit J, Derreumaux P, Tuffery P. 2010. A fast and accurate method for large-scale de novo peptide structure prediction. J Comput Chem. 31:726-738.

Monteiro S, Carreira A, Freitas R, Pinheiro AM, Ferreira RB. 2015. A nontoxic polypeptide oligomer with fungicide potency under agricultural conditions which is equal or grater than that of their chemical counterpart. PLoS ONE. 10:e122095.

Nguyen LT, de Boer L, Zaat SAJ, Vogel HJ. 2011. Investigating the cationic side chains of the antimicrobial peptide tritrpticin: Hydrogen bonding properties govern its membrane-disruptive activities. Biochim Biophys Acta. 1808:2297-2303.

Nielsen SL, Frimodt-Moller N, Kragelund BB, Hansen PR. 2007. Structure-activity study of the antibacterial peptide fallaxin. Protein Sci. 16:1969-1976.

Potocnik K, Gantner V, Kuterova K, Cividini A. 2011. Mare's milk: Composition and protein fraction in comparison with different milk species. Mljekarstvo. 61:107-113.

Prior RL, Wu X, Schaich K. 2005. Standardized methods for determination of antioxidant capacity and phenolics in foods and dietary supplements. J Agric Food Chem. 53:4290-4302.

Rahnamaeian M, Cytrynska M, Zdybicka-Barabas A, Dobslaff K, Wiesner J, Twyman RM, Zuchner T, Sadd BM, Regoes RR, Schimid-Hempel P, Vilcinskas A. 2015. Insect antimicrobial peptides show potentiating functional interactions againts Gram-negative bacteria. Proc R Soc B. 282:1-10.

Rath A, Glibowicka M, Nadeu VG, Chen G, Deber CM. 2009. Detergent binding explains anomalous SDS-PAGE migration of membrane proteins. PNAS. 106:17601765 .

Rosenfeld Y, Lev N, Shai Y. 2010. Effect of the hydrophobicity to net ositive charge ratio on antibacterial and anti-endotoxin activities of structurally similar antimicrobial peptide. Biochemistry. 49:853861.

Saravan R, Bhattacharjya S. 2011. Oligomeric structure of chatelicidin antimicrobial peptide in dodecylphosphocholine micelle determined by NMR spectroscopy. Biochimica et Biophysica Acta. 1808:369-381.

Shen Y, Maupetit J, Derreumaux P, Tuffery P. 2014. Improved PEP-FOLD approach for peptide and miniprotein structure prediction. Int Chem Theor Comput. 10:4745-4758.

Thaipong K, Boonprakob U, Crosby K, Cisneros-Zevallos L, Byrne DH. 2006. Comparison of ABTS, DPPH, FRAP, and ORAC assays for estimation antioxidant activity from guava fruit extracts. J Food Comp Anal. 19:66967.

Thevenet P, Shen Y, Maupetit J, Guyon F, Derreumaux P, Tuffery P. 2012. PEP-FOLD: an updated de novo structure prediction server for both linear and disulfide bonded cyclic peptides. Nucleic Acids Res. 40:W288293.

Uniacke-Lowe T, Huppertz T, Fox P. 2010. Equine milk protein: Chemistry, structure and nutritional significance. Int Dairy J. 20:609-629.

Vermeer LS, Abbate V, Ruh E, Bui TT, Wilkinson LJ, Kanno T, Jumagulova E, Kozlowska J, Patel J, McIntyre CA, Yam WC, Siu G, Atkinson AA, Lam JKW, Bansal SS, Drake AF, Mitchell GH, Mason AJ. 2012. Conformational flexibility determines selectivity and antibacterial, antiplasmodial, and anticancer potency of cationic $\alpha$-helical peptides. J Biol Chem. 287:3412034133 .

Wilcks A, Smidt L, Bahl MI, Hansen BM, Andrup L, Hendriksen NB, Licht TR. 2008. Germination and conjugation of Bacillus thuringiensis subsp. israelensis in the intestine of gnotobiotic rats. J Appl Microbiol. 104:1252-1259.

Zhang Z, Hao H, Tang Z, Zou Z, Zhang K, Xie Z, Babe L, Goedegebuur $\mathrm{F}, \mathrm{Gu}$ X. 2015. Identification and caharacterization of a new alkaline thermolysine-like protease, BtsLP1, from Bacillus thuringiensis serovar Sichuansis strain MC28. J Microbiol Biotechnol. 25:1281-1290.

Zhou G, Liu H, Yuan Y, Yuan Z. 2008. The occurrence of Bacillus cereus, B. thuringiensis and B. mycoides in Chinese pasteurized full fat milk. Int J Food Microbiol. 121:1995-2000 